\title{
Larval growth in the dominant polychaete Polydora ciliata is food-limited in a eutrophic Danish estuary (Isefjord)
}

\author{
Troels Møller Pedersen ${ }^{1}$, Rodrigo Almeda ${ }^{2}$, Frank Lech Fotel ${ }^{1,4}$, \\ Hans Henrik Jakobsen ${ }^{3}$, Patrizio Mariani ${ }^{3}$, Benni Winding Hansen ${ }^{1, *}$
}

${ }^{1}$ Roskilde University, Department of Environmental, Social and Spatial Change, PO Box 260, 4000, Roskilde, Denmark

${ }^{2}$ Institut de Ciènces del Mar, CSIC, P. Marítim de la Barceloneta 37-49, 08003 Barcelona, Catalunya, Spain

${ }^{3}$ National Institute of Aquatic Resources, Technical University of Denmark, Kavalergården 6, 2920 Charlottenlund, Denmark

${ }^{4}$ Present address: DHI Water \& Environment, Agern Allé 5, 2970 Hørsholm, Denmark

\begin{abstract}
Food limitation in larval growth of the spionid polychaete Polydora ciliata was examined in a typical eutrophic estuary, Isefjord, in Denmark. In the field, food availability and the energetic requirements of the $P$. ciliata larval population were measured during 2 different periods in 2004 and 2007 that together cover the productive part of the year for plankton. In the laboratory, specific growth rates $(\mu)$ of larvae reared on natural food suspensions $\left(\sim 0.10 \mathrm{~d}^{-1}\right)$ were always lower than those of larvae reared on phytoplankton-enriched food suspensions $(100 \%$ retention efficiency for

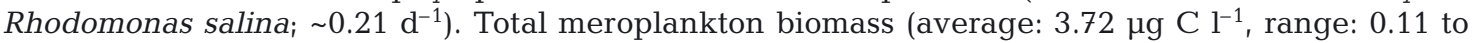
$26.05 \mu \mathrm{g} \mathrm{C}^{-1}$ ) was frequently similar to or exceeded that of holoplankton (average: $5.70 \mu \mathrm{g} \mathrm{C}^{-1}$, range: 0.08 to $29.89 \mu \mathrm{g} \mathrm{Cl}^{-1}$ ), suggesting a trophic significance of meroplankton in the estuary. P. ciliata was commonly the dominant meroplanktonic larvae (average: $0.5 \mu \mathrm{g} \mathrm{Cl}^{-1}$, range: 0.03 to $2.51 \mu \mathrm{g}$ $\left.\mathrm{C}^{-1}\right)$. The available food in the optimal prey size fraction $\left(2004\right.$, average: $<20 \mu \mathrm{m}_{\text {; }}$ range: 99 to $274 \mu \mathrm{g} \mathrm{Cl}^{-1}$; 2007, average: 7 to $18 \mu \mathrm{m}$; estimated carbon demand: $119 \mu \mathrm{g} \mathrm{C} \mathrm{l}^{-1}$; range: 19 to $474 \mu \mathrm{g}$ $\mathrm{C}^{-1}$ ) seemed to be sufficient to cover the energetic carbon requirements of the population throughout the study ( 0.09 to $3.15 \mu \mathrm{g} \mathrm{C} \mathrm{l}^{-1} \mathrm{~d}^{-1}$ ), but insufficient to attain the maximum specific growth rates reported in previous laboratory experiments. This suggests that $P$. ciliata larvae probably exhibit a low feeding efficiency and their maximum specific growth rates are consequently attained at food concentrations even higher than those found in this eutrophic environment.
\end{abstract}

KEY WORDS: Food limitation $\cdot$ Larval growth $\cdot$ Polydora ciliata $\cdot$ Larvae

\section{INTRODUCTION}

Spawning of benthic invertebrates, including Polydora ciliata, results in the release of a large number of planktonic larvae (meroplankton) which spend a variable period of time, from minutes to months, in the water column (Thorson 1950, 1964). Since planktonic food resources are highly patchy, it is likely that larvae are often food limited in natural environments, i.e. natural food concentrations are below those required to support maximum rates of growth and development (Olson \& Olson 1989, Fenaux et al. 1994). Food limita- tion prolongs the planktonic period and increases the exposure of larvae to other sources of mortality such as predation (Thorson 1950). Consequently, food limitation during the planktonic larval stages is suggested to decrease recruitment into benthic populations (Thorson 1950, Vance 1973, Olson \& Olson 1989).

Beside food quantity, food quality should be taken into account as well when evaluating potential food-limited growth in nature. Plankton cells may be too large or small for larvae to catch and ingest and can vary considerably in nutritional quality (Pechenik 1987). Bivalve, gastropod and many capitellid polychaete larvae retain 
food particles in the nano-fraction ( 2 to $20 \mu \mathrm{m}$ ) from a few to $15 \mu \mathrm{m}$ equivalent spherical diameter (ESD) (Riisgård et al. 1980, Hansen 1993, Raby et al. 1997). In contrast, small spionid polychaete larvae (5 to 10 setigers) are able to ingest large centric diatoms, e.g. Coscinodiscus spp. (Anger et al. 1986). Recent experiments indicate that the particle regime which Polydora ciliata can exploit increases during the larval ontogeny from 4 to $50 \mu \mathrm{m} \mathrm{ESD,}$ and the optimal food size for small larvae $(230 \pm 30 \mu \mathrm{m}$ in length) is around $12 \mu \mathrm{m}$ (Hansen et al. unpubl.). A similar ontogenetic development of the retention spectra has previously been reported in gastropod veliger larvae (Hansen 1991). Thus, food limitation is not solely due to a general low food concentration; i.e. a match between available food size and the physiological capabilities of the larvae is also crucial for optimal feeding and growth.

Food limitation is thought to be more important for crustacean larvae than for the ciliated larvae of bivalves and echinoderms (Olson \& Olson 1989). Furthermore, food limitation is expected to be less important in coastal waters than in oceanic waters (Huntley \& Boyd 1984). However, food limitation in coastal waters has been reported for bivalve (Fotel et al. 1999) and echinoderm larvae (Fenaux et al. 1994, Eckert 1995). In case of polychaete larvae, studies are very scarce but the existing research suggests food-limited growth during summer (Paulay et al. 1985, Hansen 1999).

Spionid polychaetes, and very often Polydora spp., are among the most common invertebrates in neritic benthic environments. During certain periods, their planktotrophic larvae can be the major component of meso-

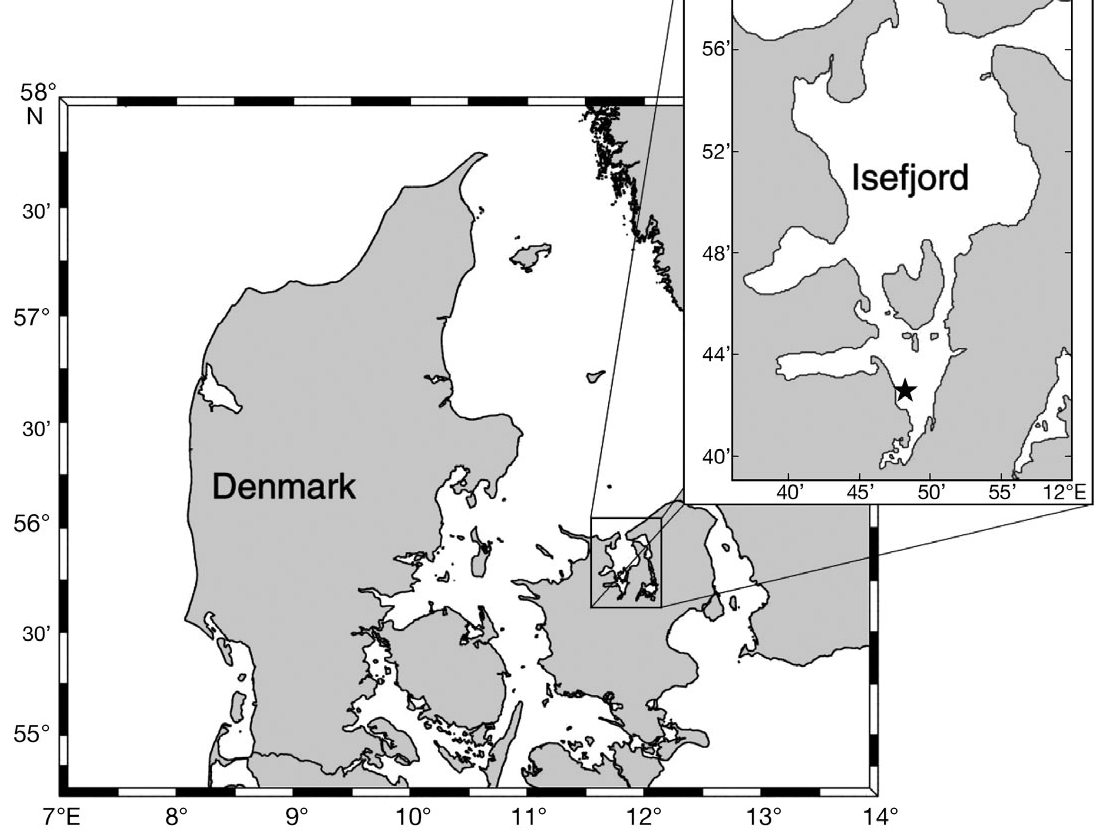

Fig. 1. Søminestationen sample station $(\star)$ in the Danish estuarine system, Isefjord $\left(55^{\circ} 42^{\prime} 44.45^{\prime \prime} \mathrm{N}, 11^{\circ} 47^{\prime} 45.48^{\prime \prime} \mathrm{E}\right)$ zooplankton (200 to $2000 \mu \mathrm{m}$ ) (Schram 1968, Anger et al. 1986 and references therein, Zajac 1991, Pedersen et al. 2008), suggesting an important role as grazers on primary producers. However, the possible trophic function in the marine carbon flow of polychaete larvae, as well as other meroplanktonic larvae, remains largely unknown. In order to fully understand the function of planktotrophic larvae in the ecosystem, their temporal and spatial abundance as well as their physiological requirements must be assessed.

The objectives of the present study were to first test if larvae of the spionid polychaete Polydora ciliata exhibited food-limited growth in situ throughout the entire productive part of year in plankton. To address this topic we carried out 2 experimental approaches: (1) we determined the food availability (in terms of quantity and quality [size]) for $P$. ciliata larvae in its habitat and evaluated if it was enough to support the maximum growth rates in situ as observed in previous laboratory experiments (Almeda et al. 2009); (2) we assessed the degree of food limitation by comparing growth rates of larvae reared on natural food suspensions with those reared on natural food suspensions enriched with cultivated phytoplankton (Rhodomonas salina) in excess in the laboratory. The second objective of the present study was to estimate the energy requirements of $P$. ciliata larval populations and their trophic significance.

\section{MATERIALS AND METHODS}

Field site and sampling. The present study was conducted during 2 periods in 2004 (April to September) and 2007 (September to November), covering the entire productive part of the year, at the field station Søminestationen (Fig. 1) situated in the Isefjord, Denmark. The field site has a depth of $4 \mathrm{~m}$ and is characterized by muddy bottom sediments and eutrophic waters (Rasmussen 1973), being a relevant example of a boreal shallow water estuary (Conley et al. 2000).

Quantitative zooplankton samples were collected every 3 to 4 wk by duplicate hauls in 2004 and more frequently (every second day to second week) by single hauls in 2007. The hauls were conducted from bottom to surface with a $45 \mu \mathrm{m}$ mesh size WP-2 net equipped with a closed cod-end and a digital flow meter (Hydro Bios, model 438 110). Samples were gently concentrated on a 
$45 \mu \mathrm{m}$ screen and stored in containers with 80 to $96 \%$ ethanol in final concentration.

Live zooplankton for growth experiments were gently collected by trawling the WP-2 net equipped with a 11 closed cod-end at slow speed through surface water ( 0 to $2.5 \mathrm{~m}$ ). Immediately after the net was retrieved, zooplankton were diluted by surface water and brought to the laboratory in a 501 thermo box.

Seawater samples for food availability studies and growth experiments were collected every second day during growth incubation experiments. The discrete samples were taken at $0,1,2,3$ and $4 \mathrm{~m}$ depth by a 31 heart-valve water bottle sampler pooled in a 301 bucket; these were considered integrated water column samples. Temperature was also measured every second day during growth incubation experiments by a thermometer attached to the sampling bottle, and salinity was determined by a hand-held refractometer (ATAGO) with a resolution of 0.5 salinity units.

Food availability. According to an ongoing study (Hansen et al. unpubl.), the particle regime Polydora ciliata can exploit increases during the larval development from 4 to $50 \mu \mathrm{m}$ ESD, and the optimal food size for small larvae $(230 \pm 30 \mu \mathrm{m}$ in length) is around $12 \mu \mathrm{m}$ (range: 7 to $18 \mu \mathrm{m}$ ). Therefore, large phytoplankton chains or colonies can most likely not be captured by $P$. ciliata larvae. We used 2 experimental approaches to determine the food availability for $P$. ciliata larvae: (1) fractioned chlorophyll a (chl a) measurements and (2) plankton community analysis.

Fractioned chl a measurements: We fractionated collected seawater through Nitex screens and into different size fractions $(<20,20-50,50-200$ and $>200 \mu \mathrm{m})$ in order to assess the available phytoplankton biomass for Polydora ciliata larvae. Water samples $(50 \mathrm{ml})$ of each fraction were filtered in triplicate through $\mathrm{GF} / \mathrm{F}$ filters by use of syringes and filter capsules. The filters with retained particles were extracted overnight in $96 \%$ ethanol as the extraction solvent (according to Jespersen \& Christoffersen 1987). If necessary, the extract was filtered through $0.2 \mu \mathrm{m}$ filter capsules or centrifuged to get rid of particles. Chl $a$ and phaeopigments in the extractions were measured in quartz glass cuvettes on a Turner Designs 700 fluorometer.

Plankton community analysis: We analysed the size structure and morphological composition of the plankton community in order to assess the available food for Polydora ciliata. Samples of natural seawater were fixed in acid Lugol's to a final concentration of $5 \%$, stored in brown glass bottles and analysed in an automated microscope (FlowCAM ${ }^{\circledR}$, www.fluidimaging. com) within $48 \mathrm{~h}$ after fixation. Each sample was analysed in triplicate for $20 \mathrm{~min}$. Images of plankton particles were continuously acquired by a video camera. The automated microscope counted and regis- tered the metric dimensions of the particles and assigned a unique identifier to each which was used later for image retrieval and sample analysis (Sieracki et al. 1998). We used the autoimage mode data acquisition in the software package VisualSpreadsheet (VISP, v 1.5.16, www.fluidimaging.com) with a minimal particle size of $5 \mu \mathrm{m}$. The procedure allowed us to derive individual particle width $(W)$ and length $(L)$, while particle volume $(V)$ was calculated assuming prolate spheroid particle shapes:

$$
V=\frac{\pi \times W^{2} \times L}{6}
$$

The aspect ratio $(W / L)$ was used to differentiate between chain-formed and spherical particles. The relevant aspect ratio was decided for each sample run, but it was typically around 0.4. The individual particle volumes were converted to cell carbon using the carbon:volume relationship given by Montagnes et al. (1994) for autotrophic flagellates (spherical particles). The chain-formed particles presented a different challenge. Because chains are formed by smaller cells with similar carbon content, we applied a constant carbon:volume relationship. This fixed value was based on inspections of the images generated by the FlowCAM which revealed dominance of diatoms of the species Skeletonema cf. costatum during periods when chain-formed particles were present. Typically, these cells had a size of $20 \mu \mathrm{m}$ which corresponds to a carbon:volume ratio of 0.06 using the appropriate isometric carbon:volume relationship for diatoms (Montagnes et al. 1994).

Total phytoplankton biomass $\left(\mu \mathrm{g} \mathrm{Cl}^{-1}\right)$ was regressed against the measured $\mathrm{chl} \mathrm{a}\left(\mu \mathrm{g} \mathrm{chl} \mathrm{a} \mathrm{l}^{-1}\right)$ to obtain a conversion factor. This conversion factor was applied to calculate the available phytoplankton biomass in term of carbon from the chl a measurements.

Growth experiments. We carried out 9 growth experiments during the 2 study periods (Table 1). Polydora ciliata larvae were concentrated from the container by light attraction using a cold fiber optic light source. Early larvae $(<300 \mu \mathrm{m}$ in length) were sorted with a pipette under a dissecting microscope and incubated within a few hours from collection. Larvae were incubated for $5 \mathrm{~d}$ in 2 types of food treatments ( 3 to 5 replicates per treatment except in September 2004, see 'Results'): (1) natural seawater from the sampling site (screened through $200 \mu \mathrm{m}$ ), i.e. natural food suspensions; and (2) natural seawater (screened through $200 \mu \mathrm{m}$ ) with added culture phytoplankton (Rhodomonas salina, 9 to $10 \mu \mathrm{m}$ ESD) in excess, i.e. enriched food suspensions.

Excess of food ( 40000 cells ml ${ }^{-1}$ ) was obtained from published saturation levels of functional food responses according to Almeda et al. (2009). Incubations were conducted in $70 \mathrm{ml}$ acid-washed glass bottles 
Table 1. Polydora ciliata. Larval concentration and initial and final larval length in the growth experiments ( ${ }^{*}$ converted from number of setigers according to Hansen 1999). Percent cleared in the bottles per day is calculated from the clearance rate versus body length relationship presented in Hansen et al. (unpubl.). The minimum and maximum clearance is based on the initial and final body length, respectively, and the intermediate is an average of the 2, each in natural food suspension. Estimates of the pelagic life span are based upon the growth rates in natural and enriched food suspension. In these estimates the initial length was set to 2.5 setigers and the length at metamorphosis was set to 17 setigers (Anger et al. 1986)

\begin{tabular}{|c|c|c|c|c|c|c|c|c|c|c|}
\hline \multirow[t]{2}{*}{ Year } & \multirow{2}{*}{ Experiment } & \multirow{2}{*}{$\begin{array}{c}\text { Larval } \\
\text { oncentration } \\
\text { (larvae } \mathrm{ml}^{-1} \text { ) }\end{array}$} & \multirow{2}{*}{$\begin{array}{l}\text { Initial larval } \\
\text { length } \\
(\mu \mathrm{m})\end{array}$} & \multicolumn{2}{|c|}{$\begin{array}{l}\text { Final larval length } \\
\qquad(\mu \mathrm{m})\end{array}$} & \multicolumn{3}{|c|}{$\begin{array}{c}\text { Bottle volume cleared } \\
\qquad\left(\% \mathrm{~d}^{-1}\right)\end{array}$} & \multicolumn{2}{|c|}{$\begin{array}{l}\text { Pelagic life span } \\
\text { (d) }\end{array}$} \\
\hline & & & & Natural & Enriched & Min. & Intermediate & Max. & Natural & Enriched \\
\hline \multirow[t]{4}{*}{2004} & May & 0.5 & $388.8 \pm 18.5^{*}$ & $645.8 \pm 17.2^{*}$ & $801.8 \pm 50.7^{*}$ & 37.5 & 48.8 & 60.0 & 42.8 & 27.4 \\
\hline & Jun & 0.5 & $245.9 \pm 16.4^{*}$ & $421.7 \pm 33.4^{*}$ & $678.5 \pm 42^{*}$ & 21.5 & 31.0 & 40.5 & 47.9 & 19.7 \\
\hline & Aug & 0.5 & $127.3 \pm 0^{*}$ & $342.2 \pm 95.9^{*}$ & $663.1 \pm 50^{*}$ & 11.5 & 21.0 & 30.5 & 23.9 & 12.3 \\
\hline & Sep & 0.5 & $241.3 \pm 23^{*}$ & $462.1 \pm 58.9^{*}$ & $488.1 \pm 25.8^{*}$ & 21.0 & 32.0 & 43.0 & 46.4 & 38.9 \\
\hline \multirow[t]{5}{*}{2007} & Sep (initial) & 1.43 & $229.4 \pm 14.5$ & $283.6 \pm 17.2$ & $524.2 \pm 12.1$ & 57.1 & 64.3 & 71.4 & 57.8 & 15.0 \\
\hline & Sep (terminal 1) & 1.43 & $217.7 \pm 25.3$ & $313.4 \pm 12.7$ & $435.7 \pm 17.6$ & 54.3 & 68.6 & 82.9 & 32.8 & 17.2 \\
\hline & Sep (terminal 2) & 0.86 & $212.9 \pm 60.6$ & $283.7 \pm 8.5$ & $350.5 \pm 7.8$ & 31.7 & 37.3 & 42.9 & 29.8 & 17.1 \\
\hline & Oct & 0.71 & $295.2 \pm 52.5$ & $452.4 \pm 5.6$ & $612.5 \pm 33.1$ & 38.6 & 49.6 & 60.7 & 27.0 & 16.0 \\
\hline & Nov & 0.57 & $244.1 \pm 1.8$ & $318 \pm 14.6$ & $490.4 \pm 7.8$ & 24.0 & 28.9 & 33.7 & 49.5 & 17.0 \\
\hline
\end{tabular}

placed on a plankton wheel at $0.5 \mathrm{rpm}$ in dim light at $16^{\circ} \mathrm{C}$. Larval densities varied depending on the experiment (Table 1). In the September terminal 1 experiment, we conducted an additional growth experiment (September terminal 2) with a different larval density in order to assess possible crowding effects. An initial subsample of larvae from each experiment was taken and fixed for length and setiger number determination. Every second day, $80 \%$ of the food suspension was removed by inverse filtration through $45 \mu \mathrm{m}$ mesh and the suspension renewed from pre-screened integrated in situ seawater collected the same day from the sampling area (for natural food suspensions) or by Rhodomonas salina in excess (enriched food suspensions). At the end of the incubation, larvae from each experimental bottle were concentrated and fixed with acid Lugol's solution for later size measurements.

Larval specific growth rates were estimated from the increases in somatic biomass according to the expression for logarithmic growth:

$$
\mu=(24 / T) \times \ln \left(W_{\mathrm{f}} / W_{\mathrm{i}}\right)
$$

where $T$ is the duration of incubation (h) and $W_{\mathrm{i}}$ and $W_{\mathrm{f}}$ are the initial and final carbon biomasses of the larvae $(\mu \mathrm{g})$, respectively.

In 2004, larval biomasses were estimated by counting the number of setigers $\left(\sim 30\right.$ larvae replicate $\left.{ }^{-1}\right)$. Average number of setigers $(S)$ was converted to carbon biomass $(W, \mu g)$ according to the equation (Hansen 1999):

$$
W=\left(6.81 \times 10^{-3}\right) S^{2.03}, \mathrm{R}^{2}=0.990
$$

In 2007, larval biomasses were estimated by measuring body length $\left(\sim 40\right.$ larvae replicate $\left.{ }^{-1}\right)$. We converted average larval length $(L, \mu \mathrm{m})$ to carbon biomass ( $W$, $\mu g)$ according to the equation (Hansen 1999):

$$
W=\left(1.58 \times 10^{-4}\right) L^{1.38}, \mathrm{R}^{2}=0.996
$$

Setiger counting was carried out under an inverted microscope $(100 \times)$. To measure body length, preserved larvae were placed under a dissecting microscope equipped with a digital camera and at least 40 images of random chosen larvae were taken per bottle $(40 \times$ or inverted microscope $[100 \times]$, depending on the experiment). These images were used with ImageJ software to measure length.

Zooplankton abundance and energy requirements. Quantitative zooplankton samples were split by a Folsom plankton splitter and a minimum of 300 individuals were counted and identified. Carbon biomass of the individual zooplankton taxa, including Polydora ciliata larvae, was estimated using the formulas reported by Nielsen et al. (2007, their Table 5.1).

Energy requirements of the population of Polydora ciliata larvae were determined in terms of estimated carbon demand (ECD) according to equation:

$$
\mathrm{ECD}=(P \mu) / \mathrm{GGE}
$$

where $P$ is the population biomass of $P$. ciliata larvae $\left(\mu \mathrm{g} \mathrm{C}{ }^{-1}\right), \mu$ is the specific growth rate $\left(\mathrm{d}^{-1}\right)$ and GGE (= specific carbon growth/specific carbon ingestion) is the gross growth efficiency assumed equal to $0.29, \mathrm{R}^{2}=$ 0.98 (Almeda et al. 2009). The population biomass of $P$. ciliata larvae was calculated as an average for each relevant month and the specific growth rates determined in our growth experiments were used.

Growth data were not normally distributed because of 2 outliers. Levine's test indicated that variances 
were homogeneous, so further analysis was conducted on untransformed data. A 2-way ANOVA (Systat v.11) was conducted to determine the effects of treatment, time of growth experiment and their interaction on the specific growth rates. Multiple comparisons of significant effects were conducted with Bonferroni-corrected probabilities for planned comparisons, in particular comparing treatment for each experiment and seasonal differences within each treatment.

\section{RESULTS}

\section{Abiotic factors and food availability}

Temperature showed a typical seasonal pattern with spring temperatures of $\sim 10^{\circ} \mathrm{C}$, increasing in summer to around $20^{\circ} \mathrm{C}$, then declining throughout fall to $\sim 5^{\circ} \mathrm{C}$ (Fig. 2A). The salinity differed by $\sim 5$ units between September 2004 and September 2007 (Fig. 2A). Total
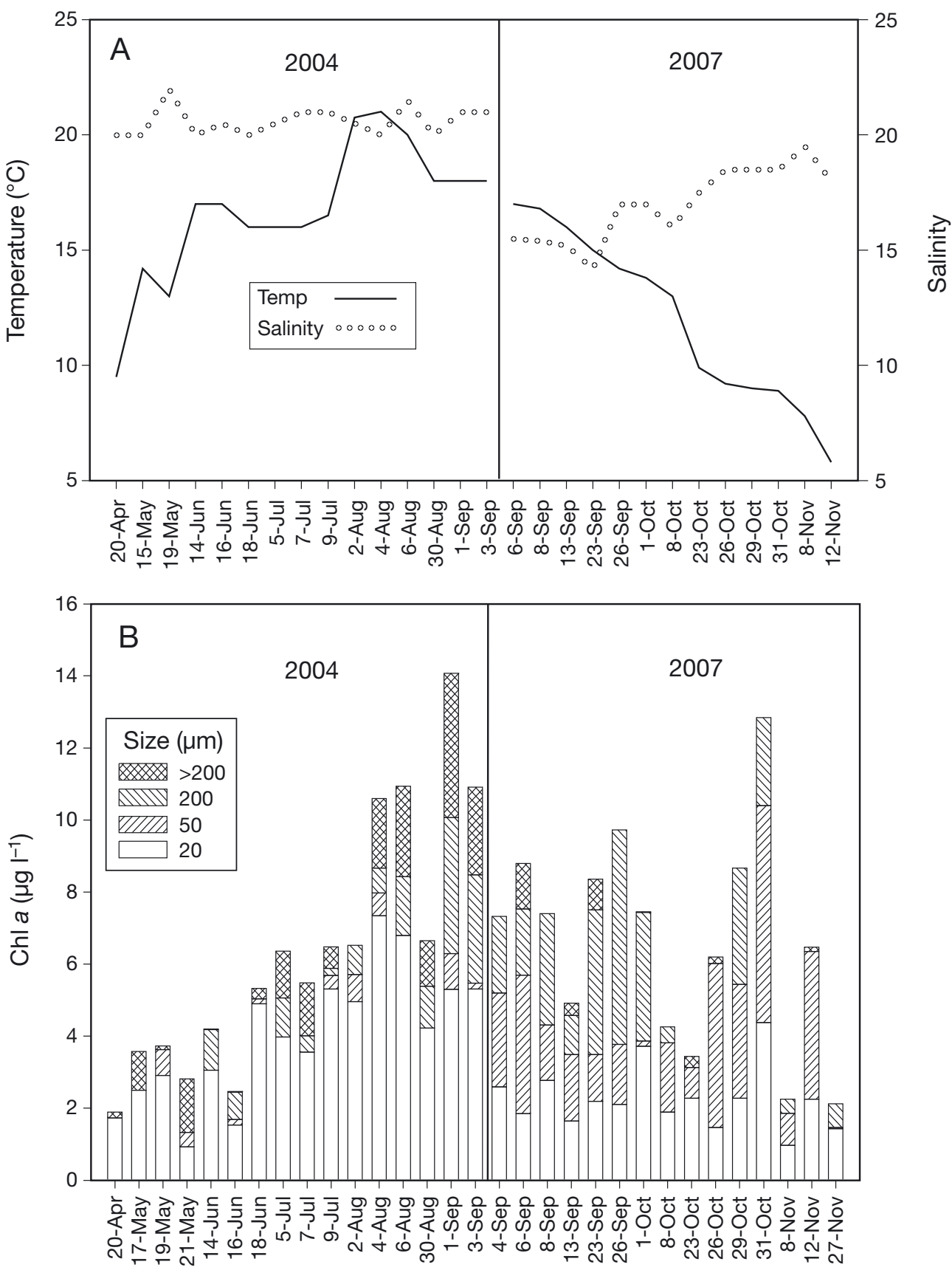

Fig. 2. (A) Integrated temperature and salinity and (B) size composition of the in situ phytoplankton community in Isefjord during the experimental periods in 2004 and 2007 
chl a (Fig. 2B) reflects the bell-shaped pattern of the water temperature generated by the global radiation, with spring values of 2 to $3 \mu \mathrm{g} \mathrm{chl} \mathrm{a} \mathrm{^{-1 }}$; values

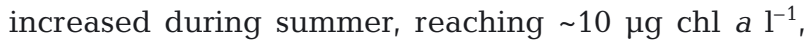
and then declined with some fluctuations through the fall. The $<20 \mu \mathrm{m}$ phytoplankton size fraction was dominant most of the time from April to September 2004 (Fig. 2B) except 21 May, when the $>200 \mu \mathrm{m}$ size fraction was prevalent. In September 2007, phytoplankton were more or less equally distributed among 3 size classes $(<20 \mu \mathrm{m}, 20-50 \mu \mathrm{m}, 50-200 \mu \mathrm{m})$ except on 23 and 26 September, when the $50-200 \mu \mathrm{m}$ size fraction dominated. During October and November 2007, the 20-50 $\mathrm{m}$ phytoplankton size fraction became more dominant until late November, when the phytoplankton present was either $<20$ or $50-200 \mu \mathrm{m}$. Phytoplankton $>200 \mu \mathrm{m}$ were mostly found in August and the beginning of September 2004.

Plankton biomass dynamics in 2007 estimated by the FlowCAM are shown in Fig. 3. The study site was highly dynamic in terms of plankton abundance and composition (Fig. 3A). Biomass fluctuations showed an initial dominance in chain-formed phytoplankton followed by 2 smaller biomass peaks of chain-formed particles, most likely Skeletonema cf. costatum, separated by $\sim 20$ to $30 \mathrm{~d}$. The phytoplankton biomass outside the $S$. cf. costatum peaks was characterized by smaller ellipsoid particles. In September, most of the nonchained particles were dinoflagellates such as Heterocapsa triquetra, unidentified spheroid dinoflagellates of unknown trophy, cell doublets of $S$. cf. costatum and various unidentified flagellates. After the last pulse of $S$. cf. costatum, most of the particles were $H$. triquetra and small unidentified algae, while $S$. cf. costatum was present below the detection level. Since small larvae have much narrower prey size spectra than larger larvae (Hansen et al. unpubl.), we isolated the biomass fraction available for newly hatched larvae in the range of 7 to $18 \mu \mathrm{m}$ (Fig. 3B).

Chl a was plotted against carbon, and a linear regression $( \pm \mathrm{SE})$ rendered a carbon:chl a conversion factor of $47\left(\mathrm{C}=47( \pm 11) \mathrm{chl} a-81( \pm 78) ; \mathrm{R}^{2}=0.52\right.$, $\mathrm{p}=0.0054$ ).

Available carbon biomass for the prey size ranges that can be captured by Polydora ciliata larvae in the study area, corresponding to the date of the growth experiment, is shown in Table 2.

\section{Zooplankton community and biomass of Polydora ciliata larvae}

The density and biomass of both holo- and meroplanktonic organisms are depicted in Fig. 4. Generally, both density and biomass of holo- and meroplanktonic organisms were higher in May to August 2004 than in September to November 2007. High densities of Rotifera were observed in October 2007. The holoplankton was dominated, both in density and biomass, by Calanoida (Copepoda) throughout the sampling periods, with the exception of 30 August 2004 and October 2007, when Rotifera showed high biomass and densities. The meroplankton was dominated both in density and biomass by Polychaeta in May 2004. From June to August 2004, biomass was mostly dominated by Gastropoda, whereas density was dominated by Bivalvia. Throughout the rest of the sampling period (September to November 2007), Polychaeta dominated the meroplankton.
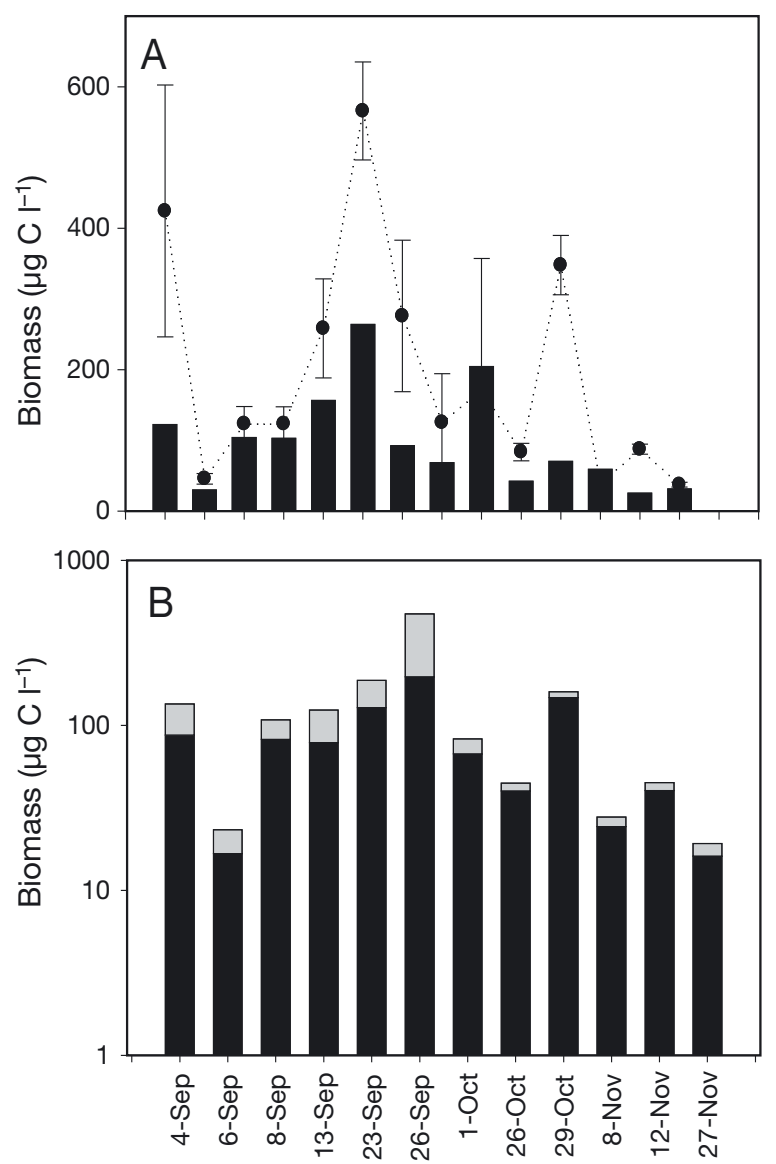

Fig. 3. Food availability in Isefjord during fall 2007 estimated by the FlowCAM. (A) Structural diversity of the standing plankton biomass. Closed circles are the total plankton biomass and the black bars are biomass of round particles (particles with aspect ratio $>0.4$ ). The difference between total carbon and round particles is mostly due to the biomass of the chain-formed diatom Skeletonema cf. costatum (B) Biomass of plankton particles in the $7-18 \mu \mathrm{m}$ size range representing the optimal prey size spectrum of Polydora ciliata small larvae, according to Hansen et al. (unpubl.). Black bars are round particles (flagellates) and gray bars are elongated particles (chain-formed particles) 
Table 2. Polydora ciliata. Available carbon biomass for the prey size ranges that can be captured by $P$. ciliata larvae in the study area corresponding to date of the growth experiments. Phytoplankton biomass was calculated by fractioned chlorophyll a measurements and plankton community by FlowCam analysis. na: not available

\begin{tabular}{|ccccc|}
\hline Year & Experiment & $\begin{array}{c}\text { Phytoplankton biomass } \\
\left(\mu \mathrm{C} \mathrm{l}^{-1}\right)\end{array}$ & $\begin{array}{c}\text { Plankton community } \\
\left(\mu \mathrm{C}^{-1}, 7-18 \mu \mathrm{m}\right)\end{array}$ \\
\hline & & $0-50 \mu \mathrm{m} \quad<20 \mu \mathrm{m}$ & na \\
2004 & May & 117 & 99 & na \\
2004 & Jun & 153 & 149 & na \\
2004 & Aug & 290 & 274 & 89 \\
2004 & Sep & 276 & 249 & 262 \\
2007 & Sep (initial) & 238 & 113 & 95 \\
2007 & Sep (terminal 1) & 169 & 93 & 31 \\
2007 & Oct & 256 & 119 & \\
2007 & Nov & 152 & 73 & \\
& & &
\end{tabular}

The relative proportion of holo- and meroplankton biomass is shown in Fig. 5. The meroplankton represented more than $50 \%$ of the planktonic biomass on 7 out of 18 sampling days, more than $80 \%$ on 3 sampling days and more than $90 \%$ of the total biomass on 26 September 2007. Hence, meroplankton indeed episodically dominated the zooplankton community.
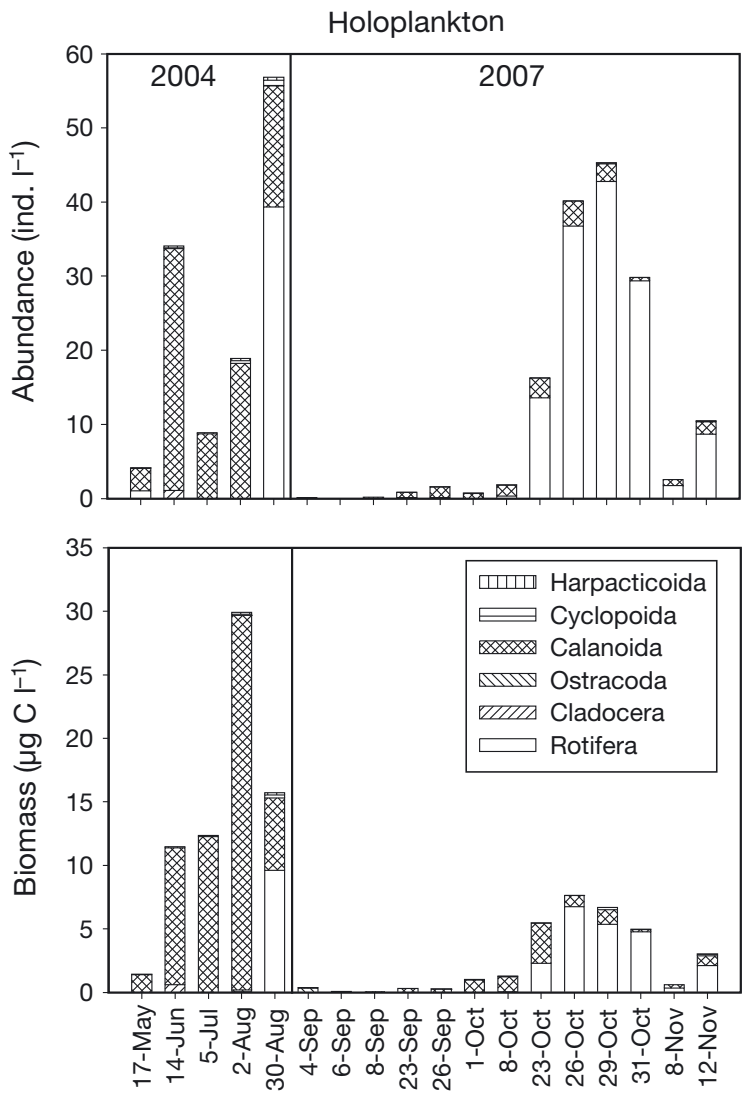

Polydora ciliata was the most dominant polychaete larvae; it constituted 20 to $100 \%$ (average: $71 \%$; Fig. 6 ) of the total polychaete larval population and was found in densities from 0.03 larvae $\mathrm{I}^{-1}$ in late October (31 Oct) to 8.05 larvae $\mathrm{l}^{-1}$ in May (17 May). On average, P. ciliata represented $38.5 \%$ of the total meroplanktonic biomass.

\section{Growth experiments}

The 2-way ANOVA showed that there was interaction between time of the growth experiments and treatment $(F=12.69, \mathrm{p}<<0.005)$. This indicates that the effect of added food on larval growth differed during the course of the year. Specific growth rates of Polydora ciliata larvae were higher when offered enriched food suspensions (Fig. 7). Based on multiple comparisons, larval growth was significantly different between treatments $(p<0.05)$ in all experiments except in May and September $2004(\mathrm{p} \leq 0.14$ and $\mathrm{p} \leq 1$,
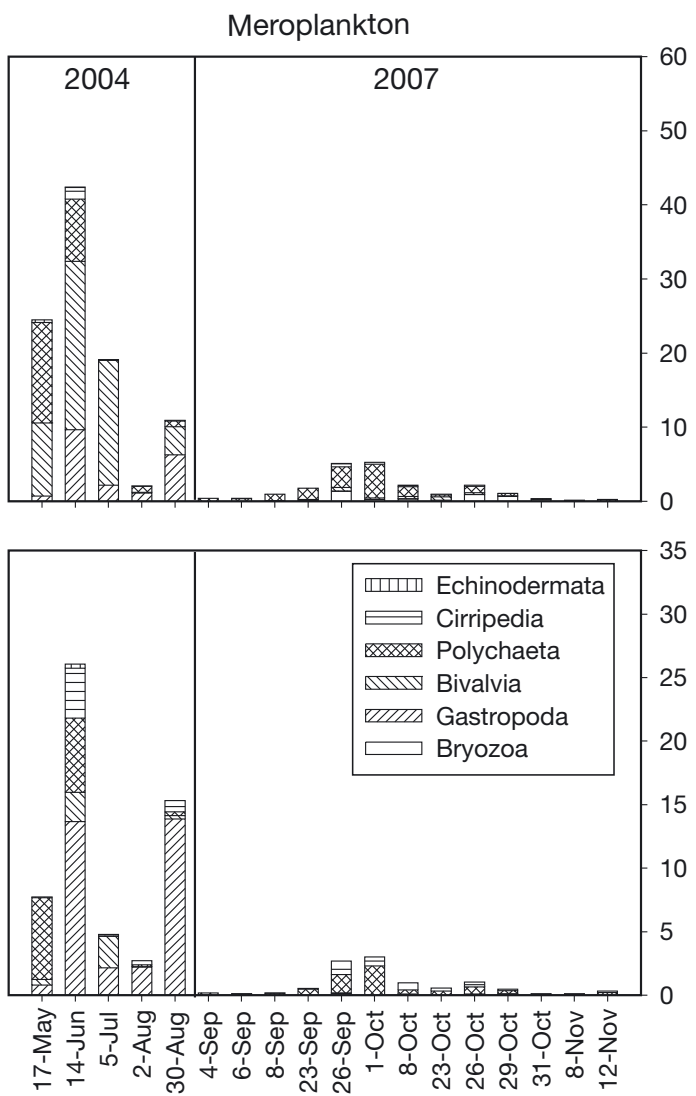

Fig. 4. Composition of the holoplankton and meroplankton in Isefjord, based on both abundance and biomass, for the 2 sampling periods in 2004 and 2007 


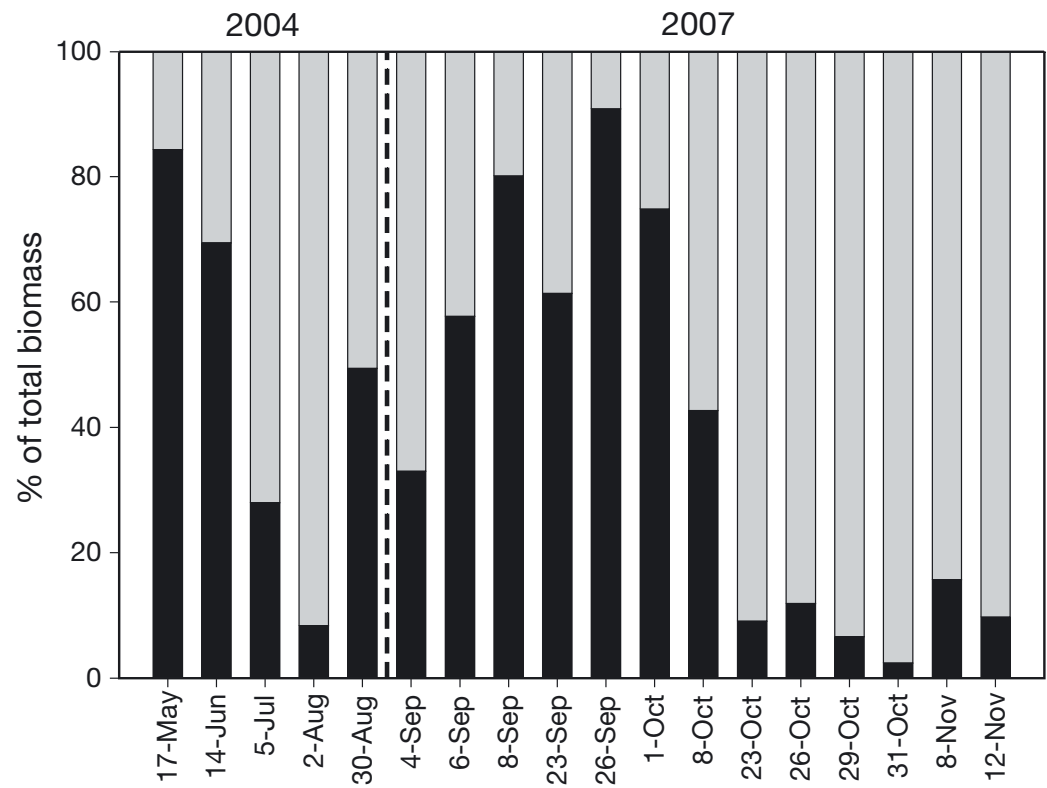

Fig. 5. Fraction of holoplankton (gray bars) and meroplankton (black bars) of the total zoo planktonic biomass in Isefjord for the 2 sampling periods in 2004 and 2007

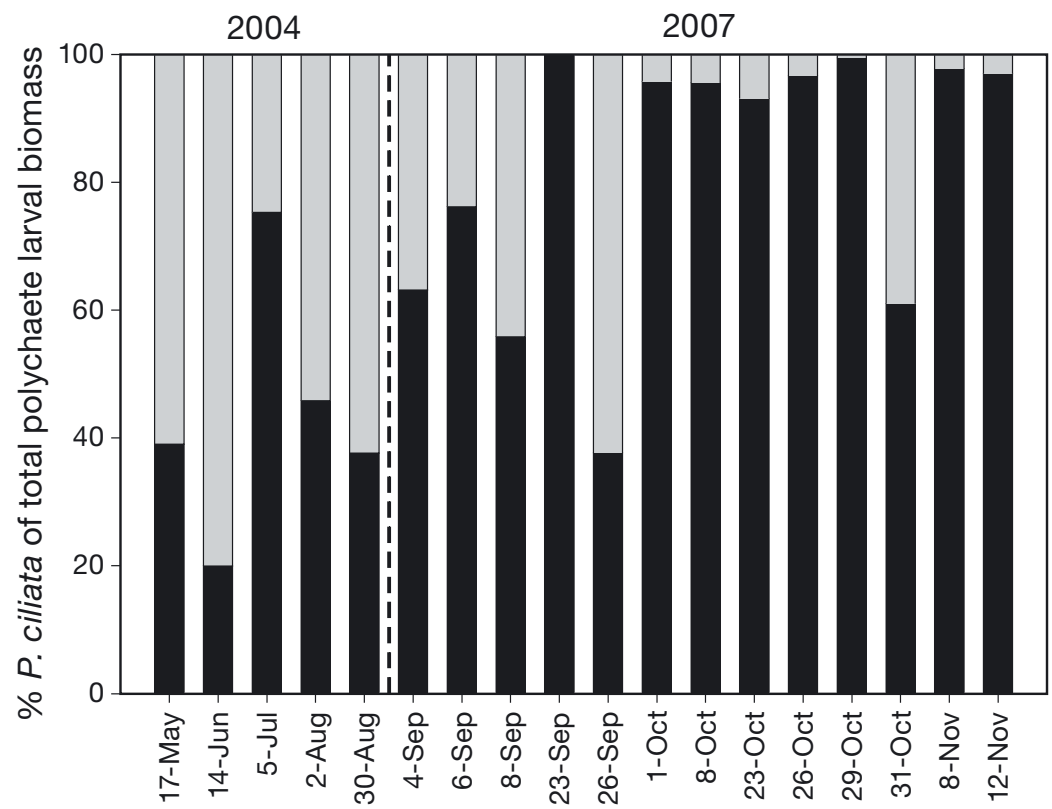

Fig. 6. Polydora ciliata. Percentage P. ciliata (black bars) of the total polychaete larval biomass (grey bars) in Isefjord for the 2 sampling periods in 2004 and 2007

showed that there was no consistent effect of enrichment. For example, in 2007, there were no significant differences between the specific growth rates from the enriched experiments, while there were significant differences between many of the specific growth rates in natural food suspensions. Furthermore, there was no significant difference between the specific growth rate in natural food suspension in May 2004 and November 2007, but there was a significant effect of treatment in November 2007 in contrast to May 2004. The overall conclusion is that enrichment stimulated the specific growth rate of $P$. ciliata larvae.

Estimates of Polydora ciliata clearance in the experimental containers under natural food conditions were based upon the relationship between body length and maximum clearance rate from Hansen et al. (unpubl.). Maximum clearance ranged between 30.5 and $82.9 \%$ of bottle volume per day (Table 1). Using initial larvae length, the minimum clearance ranged between 11.5 and $57.1 \%$ of bottle volume per day (Table 1). The intermediate clearance was an average of the minimum and the maximum volume cleared and ranged from 21 to $68.6 \%$ (Table 1 ).

The number of setigers of newly hatched larvae (2 to 3 setigers) and the number of setigers of larvae ready for metamorphosis (17 setigers, according to Anger et al. 1986) were used to estimate the pelagic life span (Table 1) under natural and enriched food conditions. An average reduction of pelagic lifespan under optimal food conditions (i.e. enriched) as compared to natural food conditions was estimated to be as much as $19.6 \mathrm{~d}$.

\section{Estimated carbon demand}

respectively). The September 2004 growth experiment was only based on 2 replicates for each treatment, which put some constrains on the interpretation of the statistical output. Average specific growth rates on natural food suspensions were $\sim 0.10 \mathrm{~d}^{-1}, 2$-fold lower than that in enriched suspensions (average: $\sim 0.21 \mathrm{~d}^{-1}$ ). Larval survival was visually checked at the end of the incubation and we did not observe evident mortality in any treatment. The multiple comparisons also
The ECD of Polydora ciliata larval population for the different growth experiments is shown in Table 3, and

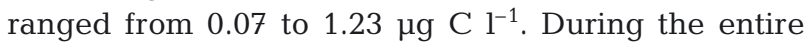
study period, the available carbon biomass (in relevant size fractions, Table 2) exceeded by several orders of magnitude the food requirements to support the maximum growth of the population (Table 3). 


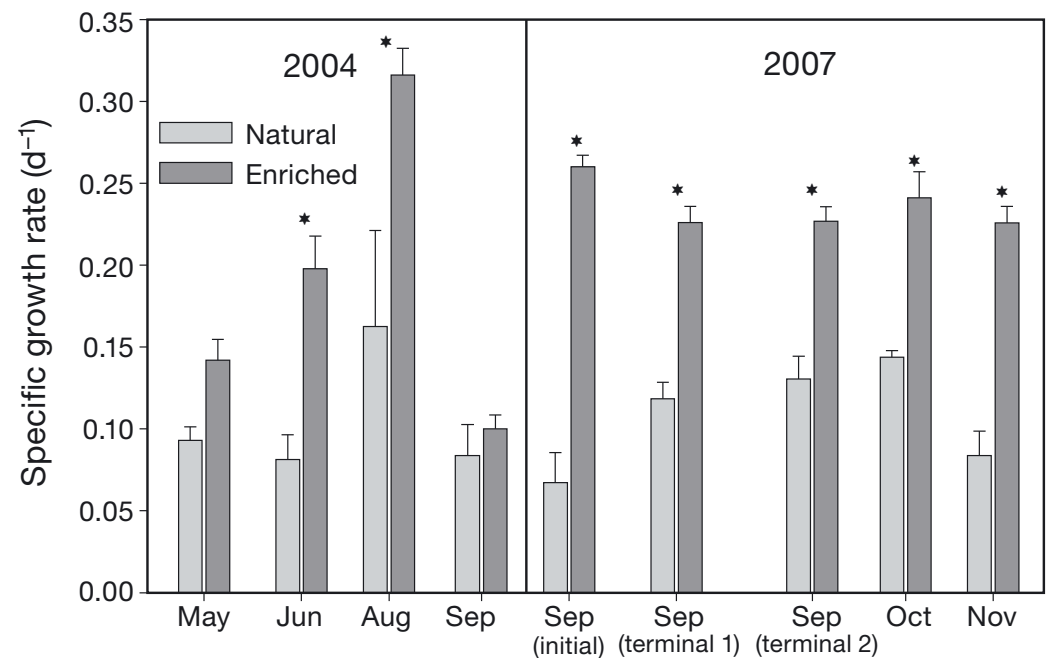

Fig. 7. Polydora ciliata. Specific growth rate $\left(\mathrm{d}^{-1}, \pm \mathrm{SD}\right)$ of $P$. ciliata larvae in natural and enriched food suspensions in Isefjord for the 2 sampling periods in 2004 and 2007. $N=35$ to 100 larvae per incubation bottle. ${ }^{*}$ Significant $(p<0.05)$ difference between treatments

Table 3. Polydora ciliata. Estimated carbon demand (ECD) of P. ciliata based upon biomass of larval population and the specific growth rates in natural and enriched food suspensions (see Eq. 5). Trophic impact equals ECD (natural) as $\%$ of the plankton community biomass in the size fraction that can be grazed by larvae $(0-50 \mu \mathrm{m})$

\begin{tabular}{|ccccc|}
\hline Year & Experiment & \multicolumn{2}{c|}{ ECD $\left(\mu \mathrm{C} \mathrm{C}^{-1}\right)$} & $\begin{array}{c}\text { Trophic impact (\%) } \\
\text { Natural }\end{array}$ \\
\hline 2004 & Natural & Enriched & $\begin{array}{c}\text { (\%) } \\
2004\end{array}$ \\
2004 & Jun & 0.81 & 1.23 & 0.69 \\
2004 & Aug & 0.33 & 0.79 & 0.21 \\
2007 & Sep & 0.03 & 0.07 & 0.01 \\
2007 & Sep (initial) & 0.02 & 0.04 & 0.01 \\
2007 & Sep (terminal 1) & 0.21 & 0.07 & 0.01 \\
2007 & Oterminal 2) & 0.23 & 0.49 & 0.12 \\
2007 & Oct & 0.30 & 0.50 & 0.14 \\
& Nov & 0.03 & 0.08 & 0.13 \\
\hline
\end{tabular}

\section{DISCUSSION}

\section{Food availability and growth rate}

According to recent laboratory studies (Almeda et al. 2009), maximum growth rates of Polydora ciliata larvae are reached, with optimal food size, at food concentrations ranging from 1410 to $2510 \mu \mathrm{g} \mathrm{C}^{-1}$ depending on larval size. During the present study periods, the phytoplankton concentrations were always lower than these critical food levels. Moreover, if we consider the size fraction of plankton that can be effectively captured by larvae, the available carbon biomass is one order of magnitude lower than the critical food levels observed in the laboratory. Therefore, P. ciliata may not grow at their maximum rates at the Isefjord study site, which is a typical example of a Danish estuary. Considering the typical food concentration of Danish estuaries around the year (Conley et al. 2000), one can extrapolate these findings to other Danish coastal environments and to the remaining part of the year. Since newly hatched larvae only ingest a rather narrow prey size between 7 and $18 \mu \mathrm{m}$ ESD (Hansen et al. unpubl.), recruitment of larger individuals is limited to the availability of particles within this size range. That is, at periods such as 26 September 2007, when we recorded the highest phytoplankton biomass, the particle window between 7 and $18 \mu \mathrm{m}$ ESD only reached $480 \mu \mathrm{g} \mathrm{C}^{-1}$, which is close to one-fifth of the required biomass for maximum growth by the early larval stage.

\section{Growth with natural vs. enriched food suspensions}

The larval specific growth patterns between the 2 years were obviously different (Fig. 7). In 2004, specific growth in natural food suspensions fluctuated more than it did in 2007, and growth in the enriched food suspensions steadily increased during 2004, whereas it was more similar and high throughout 2007. Environmental characteristics varied between the 2 years: temperature development was very different, salinity was much lower in 2007 and available food steadily increased during 2004 and was more constant during 2007. Since growth incubations were performed at constant temperature in the laboratory both years, temperature most likely cannot explain the observed larval growth differences. Differences in salinity were presumably not the cause either, since Polydora ciliata is a welladapted euryhaline species. The effect of food availability, however, may be reflected in the basic physiological condition of the larval populations. A gradual change in food concentration was reflected in a steady growth increase during 2004 for both natural and enriched food suspensions (except for the September experiment). It is more difficult, based on food availability, to explain the growth pattern observed in 2007 . Therefore, the different growth patterns in both 2004 and 2007 could be due to a combination of the effects 
of these environmental variables, or another factor altogether.

Specific growth rates of larvae reared on natural and enriched food suspensions indicated that larvae were not growing at their maximum rates in nature. Maximum growth rates observed in the enrichment treatments were similar to maximum growth rates of larvae observed under food satiating conditions in the laboratory (Almeda et al. 2009). However, artifacts from laboratory bottle incubation conditions are possible, e.g. the decline in food concentration during the $2 \mathrm{~d}$ between the water changes. The estimated clearances shown in Table 1 indicate that the larvae in 2 of the growth experiments (September initial and terminal 1 2007) could have experienced starvation through the whole experiment since the percent bottle volume cleared based upon the initial length was above $50 \%$ (57.1 and $54.3 \%$, respectively). Furthermore, some larvae in 4 of the 9 growth experiments (May 2004 and September initial, September terminal 1 and October 2007) may have experienced starvation at the end of the experiment. But if one compares September terminal 1 and 2 (Fig. 7), there was only a slight difference in growth rates in natural food suspension. Moreover, growth rates in natural food suspensions in experiments with high larval densities (e.g. September initial and terminal 1 2007) were not different to those in experiments with low larval density (e.g. November 2007). Therefore, an eventual crowding effect cannot explain the differences in growth between treatments, and the depletion of food in the experimental containers was expected to be minimally important. Hence we conclude that the observed differences in growth between treatments are not due to the depletion of food between the water changes.

In addition to food quantity, food nutritional quality may influence larval growth rates of Polydora ciliata. The copepod Temora longicornis fed on Skeletonema cf. costatum at rates comparable to feeding rates on Rhodomonas salina in the laboratory. However, the copepod egg production and somatic growth was significantly reduced compared to controls fed with $R$. salina (Dutz et al. 2008). There is growing evidence that diatoms including $S$. cf. costatum contain biomolecules aimed at defending the algae against predation (Pohnert et al. 2002, Pohnert 2005) and it is very likely that the increased growth in the $R$. salina treatments by $P$. ciliata larvae is a result of improved food quality. But to answer such question we need a thorough analysis of phytoplankton growth and nutritional status as well as other factors influencing the functional food limitation and potential active food selection of meroplanktonic organisms.

Comparing the specific growth rates in both natural and enriched food suspensions, the time required to reach metamorphosis was greatly reduced when excess food was offered (Table 1). Enriching the available food resulted in an average reduction of the pelagic life span of $19.6 \mathrm{~d}$, corresponding to a $47.6 \%$ reduction on average. On the one hand, this reduces the dispersal ratio of the propagules; on the other hand, it potentially reduces larval mortality and thereby increases benthic recruitment of Polydora ciliata larvae.

\section{Energetic carbon demand and trophic significance}

The available carbon was enough to support the food demand considering the food requirements (ECD) of Polydora ciliata. However, these larvae were not able to grow at maximum growth rates at in situ food concentrations. This suggests a low feeding efficiency and, hence, that the food limitation of larvae is functional. The food requirements of Polydora ciliata larvae constituted only negligible fractions of the standing stock of primary producers; therefore, the P. ciliata population had a very slight effect on the plankton community (low trophic impact, $<1 \%$, on total primary producers in energetic requirements, see Table 3 ). The daily food requirements (ECD) of the Polydora ciliata population corresponds well with the finding of Hansen et al. (1999) in a Greenlandic study, where meroplankton (mainly bivalves and gastropods) daily ingested just $0.12 \mu \mathrm{g} \mathrm{Cl}^{-1}$, equivalent to $0.32 \%$ of the average phytoplankton biomass.

The trophic impacts as well as the bottom-up control exerted by microzooplankton are more important factors controlling phytoplankton communities. However, larval grazing pressure on protozoans (Hansen et al. unpubl.) and associated cascading trophic effects could be a key factor structuring the planktonic microbial assemblage in coastal areas during periods with high larval abundances. This trophic interaction remains to be studied quantitatively.

Meroplankton, including polychaete larvae, is an important fraction of mesozooplankton, even periodically exceeding that of holoplankton in boreal estuaries (Blanner 1982, Hansen et al. 2002, present study). The trophic impact of other meroplanktonic larvae has been reported in Isefjord previously by Jørgensen (1981), where, based on ECD, a cohort of bivalve larvae (Mytilus edulis) daily cleared 40 to $50 \%$ of the surrounding water mass for small particles (probably flagellates). Although more information about the trophic impact of meroplankton on microbial assemblages is required, meroplanktonic larvae potentially play an important trophic role in terms of both their direct control of the microbial community and as a source of cascading effects in the microbial plankton food web 
(Martin et al. 1996). Hence we propose that meroplanktonic larvae need more attention in terms of future research and as key components structuring the planktonic microbial assemblage in boreal coastal waters.

\section{CONCLUSIONS}

The planktotrophic larvae of Polydora ciliata are functionally food limited regardless of the time of year (i.e. even during the productive part of the year), even though they inhabit a heavily eutrophic estuary. Foodlimited growth appears to be a general premise for boreal planktotrophic meroplankton (Burckhardt et al. 1997, Hansen 1999, Hansen et al. 2002, Petersen et al. 2002). The ecological consequences of growth-limited larvae could lead to a less fit juvenile population and poor post-metamorphic performance (Pechenik et al. 1996, McEdwards \& Qian 2001). The juvenile stage for benthic marine invertebrates is a vulnerable stage in the life cycle, and high mortality rates are often observed (Gosselin \& Qian 1997, Pedersen et al. 2008). This could be due to carry-over effects from the nutritional condition of the recruits, the larvae.

Acknowledgements. This work is based on research performed at Roskilde University's field station Søminestationen. We thank T. F. Sørensen and G. Drillet for assistance in the field, A. B. Faarborg and B. Søborg for chlorophyll measurements, E. M. Pedersen, K. T. Jensen and A. Winding for comments on earlier versions of the manuscript, and A. M. Palmkvist and G. Banta for statistical assistance. This project was supported by the Danish National Science Research Council (grant no. 272-07-0485) to B.W.H., an instrument grant to DTU AQUA supported by the VELUX foundation to H.H.J. and by a mobility grant to R.A. from the Spanish Ministry of Education and Science.

\section{LITERATURE CITED}

Almeda R, Pedersen TM, Jakobsen HH, Alcaraz A, Calbet A, Hansen BW (2009) Feeding and growth kinetics of the planktotrophic larvae of the spionid polychaete Polydora ciliata (Johnston). J Exp Mar Biol Ecol 382:61-68

Anger K, Anger V, Hagmeier E (1986) Laboratory studies on larval growth of Polydora ligni, Polydora ciliata, and Pygospio elegans (Polychaeta, Spionidae). Helgol Meeresunters 40:377-395

Blanner P (1982) Composition and seasonal variation of the zooplankton in the Limfjord (Denmark) during 1973-1974. Ophelia 21:1-40

Burckhardt R, Schumann R, Bochert R (1997) Feeding biology of the pelagic larvae of Marenzelleria cf. viridis (Polychaeta: Spionidae) from the Baltic Sea. Aquat Ecol 31: 149-162

Conley DJ, Kaas H, Møhlenberg F, Rasmussen B, Windolf J (2000) Characteristics of Danish estuaries. Estuaries 23: $820-837$
Dutz J, Koski M, Jonasdottir SH (2008) Copepod reproduction is unaffected by diatom aldehydes or lipid composition. Limnol Oceanogr 53:225-235

Eckert GL (1995) A novel larval feeding strategy of the tropical sand dollar, Encope michelili (Agassiz): adaption to food limitation and an evolutionary link between planktotrophy and lecithotrophy. J Exp Mar Biol Ecol 187:103-128

Fenaux L, Strathmann MF, Strathmann RR (1994) Five tests of food-limited growth of larvae in coastal waters by comparisons of rates of development and form of echinoplutei. Limnol Oceanogr 39:84-98

Fotel FL, Jensen NJ, Wittrup L, Hansen BW (1999) In situ and laboratory growth by a population of blue mussel larvae (Mytilus edulis L.) from a Danish embayment, Knebel Vig. J Exp Mar Biol Ecol 233:213-230

> Gosselin LA, Qian PY (1997) Juvenile mortality in benthic marine invertebrates. Mar Ecol Prog Ser 146:265-282

> Hansen B (1991) Feeding behaviour in larvae of the opisthobranch Philine aperta. II. Food size spectra and particle selectivity in relation to larval behaviour and morphology of the velar structures. Mar Biol 111:263-270

Hansen B (1993) Aspects of feeding, growth and stage development by trochophora larvae of the boreal polychaete Mediomastus fragile (Rasmussen) (Capitellidae). J Exp Mar Biol Ecol 166:273-288

Hansen BW (1999) Cohort growth of planktotrophic polychaete larvae - are they food limited? Mar Ecol Prog Ser 178:109-119

> Hansen BW, Nielsen TG, Levinsen H (1999) Plankton community structure and carbon cycling on the western coast of Greenland during the stratified summer situation. III. Mesozooplankton. Aquat Microb Ecol 16:233-249

Hansen BW, Stenalt E, Petersen JK, Ellegaard C (2002) Invertebrate re-colonisation in Mariager Fjord (Denmark) after a severe hypoxia. I. Zooplankton and settlement. Ophelia 56:197-213

- Huntley M, Boyd C (1984) Food-limited growth of marine zooplankton. Am Nat 124:455-478

Jespersen AM, Christoffersen K (1987) Measurements of chlorophyll a from phytoplankton using ethanol as extraction solvent. Arch Hydrobiol 109:445-454

Jørgensen CB (1981) Mortality, growth and grazing impact of a cohort of bivalve larvae, Mytilus edulis L. Ophelia 20: 185-192

> Martin D, Pinedo S, Sardá R (1996) Grazing by meroplanktonic polychaete larvae may help to control nanoplankton in the NW Mediterranean littoral: in situ experimental evidence. Mar Ecol Prog Ser 143:239-246

McEdward LR, Qian PY (2001) Effects of the duration and timing of starvation during larval life on the metamorphosis and initial juvenile size of the polychaete Hydroides elegans (Haswell). J Exp Mar Biol Ecol 261:185-197

Montagnes DJS, Berges JA, Harrison PJ, Taylor FJR (1994) Estimating carbon, nitrogen, protein, and chlorophyll a from volume in marine phytoplankton. Limnol Oceanogr 39:1044-1060

Nielsen TG, Ottosen LDM, Hansen BW (2007) Structure and function of the pelagic ecosystem in Young Sound, NE Greenland. In: Rysgaard S, Glud RN (eds) Carbon cycling in Arctic marine ecosystems: case study Young Sound. BioScience 58:87-207

Olson RR, Olson MH (1989) Food limitation of planktotrophic marine invertebrate larvae: Does it control recruitment success? Annu Rev Ecol Syst 20:225-247

Paulay G, Boring L, Strathmann RR (1985) Food limited growth and development of larvae: experiments with natural sea water. J Exp Mar Biol Ecol 93:1-10 
Pechenik JA (1987) Environmental influences on larval survival and development. In: Giese AC, Pearse JS, Pearse VB (eds) Reproduction of marine invertebrates, Vol. IX. Boxwood Press, Pacific Grove, CA, p 551-608

Pechenik JA, Hammer K, Weise C (1996) The effect of starvation on acquisition of competence and post-metamorphic performance in the marine prosobranch gastropod Crepidula fornicate (L.). J Exp Mar Biol Ecol 199: 137-152

Pedersen TM, Hansen JLS, Josefson AB, Hansen BW (2008) Mortality through ontogeny of soft-bottom marine invertebrates with planktonic larvae. J Mar Syst 73:185-207

Petersen JK, Stenalt E, Hansen BW (2002) Invertebrate recolonisation in Mariager Fjord (Denmark) after a severe hypoxia. II. Blue mussels (Mytilus edulis L.). Ophelia 56: 215-226

Pohnert G (2005) Diatom/copepod interactions in plankton: the indirect chemical defense of unicellular algae. ChemBioChem 6:946-959

Pohnert G, Lumnieau O, Cueff A, Adolph S, Cordevant C, Lange M, Poulet SA (2002) Are volatile unsaturated aldehydes from diatoms the main line of chemical defence against copepods? Mar Ecol Prog Ser 245:33-45

Raby D, Mingelbier M, Dodson JJ, Klein BW, Lacadeuc Y, Legendre L (1997) Food-particle size and selection by

Editorial responsibility: Steven Morgan,

Bodega Bay, California, USA bivalve larvae in a temperate embayment. Mar Biol 127: 665-672

Rasmussen E (1973) Systematics and ecology of the Isefjord marine fauna (Denmark). Ophelia 11:1-495

Riisgård HU, Randløv A, Kristensen PS (1980) Rates of water processing, oxygen consumption and efficiency of particle retention in veligers and young post-metamorphic Mytilus edulis. Ophelia 19:37-47

Schram TA (1968) Studies on meroplankton in the inner Oslofjord I. Composition of the plankton at Nakkeholmen during a whole year. Ophelia 5:221-243

Sieracki CK, Sieracki ME, Yentsch CM (1998) An imagingin-flow system for automated analysis of marine microplankton. Mar Ecol Prog Ser 168:285-296

Thorson G (1950) Reproductive and larval ecology of marine bottom invertebrates. Biol Rev Camb Philos Soc 25:1-45

Thorson G (1964) Light as an ecological factor in the dispersal and settlement of larvae of marine bottom invertebrates. Ophelia 1:167-208

> Vance RR (1973) On the reproductive strategies in marine benthic invertebrates. Am Nat 107:339-352

Zajac RN (1991) Population ecology of Polydora ligni (Polychaeta: Spionidae). I. Seasonal variation in population characteristics and reproductive activity. Mar Ecol Prog Ser 77:197-206

Submitted: February 24, 2009; Accepted: February 28, 2010 Proofs received from author(s): May 3, 2010 